\title{
HIV/ AIDS PREVENTION PROGRAM: A MIXED METHOD STUDY ON THE IMPLEMENTATION OF VOLUNTARY COUNSELING AND TESTING SERVICES AT PRIMARY HEALTH CENTER, JAMBI
}

\author{
Hubaybah, Evy Wisudariani, Usi Lanita \\ Faculty of Medicine and Health Sciences, Universitas Jambi
}

\begin{abstract}
Background: The number of people infected HIV/ AIDS continues to increase, including in Jambi. The reports from January to September showed 51 people with HIV infection occurred in Jambi. The accessibility of HIV/ AIDS voluntary counseling and testing (VCT) services are important in high risk area. This study aimed to investigate the HIV/ AIDS prevention program through the implementation of voluntary counseling and testing services at primary health center, Jambi.

Subjects and Method: The mix-method study was conducted at three locations, including Tanjung Pinang, Rawasari, and Pakuan Baru Community Health Centres, from March to May 2020. The study's informants were HIV/ AIDS counselors, laboratorian/ pharmacists, and HIV / AIDS risk groups who visited the VCT clinic. The data were collected through in-depth interviews and direct observations. The data were reported descriptively.

Results: The implementation of the VCT program was generally good (82\%), i.e., counselors had attended the training at least once, and the education level of health workers was standard. The health professionals were friendly and used simple and understandable language to communicate with clients. The facilities and infrastructure showed that the cleanroom was clean, but the other facilities were still incomplete. There was only one door in the counseling room and the absence of an information board for the VCT service flow. Some of these HIV/ AIDS counselors also had responsibility for some other programs besides VCT services. There was a WhatsApp group with risk groups.

Conclusion: The VCT program is well implemented. Some improvements in terms of periodic evaluation of the implementation of VCT services, upgrading staff skills and providing an adequate number of facilities and infrastructure.
\end{abstract}

Keywords: VCT, HIV/ AIDS, counsellor

Correspondence:

Hubaybah. Faculty of Medicine and Health Sciences, Universitas Jambi. Jl. Letjend Soeprapto No 33 Telanai Pura Jambi. Email: hubaybah@unja.ac.id. Mobile: +628117453224 .

The $7^{\text {th }}$ International Conference on Public Health Solo, Indonesia, November 18-19, 2020 | 146 https://doi.org/10.26911/the7thicph.02.35 